\title{
Wiestawa Leżańska
}

Uniwersytet Łódzki

\section{Edukacja obywatelska na lamach czasopisma „Oświata i Wychowanie"}

(Organ Ministerstwa Wyznań Religijnych

i Oświecenia Publicznego 1929-1938)

\section{O czasopiśmie}

W okresie dwudziestolecia międzywojennego mamy do czynienia z intensywnym rozwojem czasopiśmiennictwa, w tym pedagogicznego. Wszystkie, wydawane od roku 1927, pisma, w myśl dekretu prasowego podlegały rejestracji urzędowej. Początkowo rejestrację tę prowadził Wydział Prasowy Ministerstwa Spraw Wewnętrznych, natomiast od roku 1929 zadanie to przejął Państwowy Instytut Bibliograficzny działający przy Bibliotece Narodowej w Warszawie. Od roku 1928 prowadzono bibliografię druków, również pism, w postaci „Urzędowego Wykazu Druków”.

Sprawami pedagogicznymi zajmowało się niemal 300 tytułów. Część z nich wydawana była w językach białoruskim, niemieckim, żydowskim, łotewskim lub ukraińskim. Większość ukazywała się krótko, 61 przetrwało dłużej niż dziesięć lat, a tylko kilkanaście wychodziło przez cały okres międzywojenny.

Wśród periodyków najbardziej znanych możemy wymienić: „Epokę”, „Ogniwo”, „Miesięcznik Pedagogiczny”, „Życie szkolne”, „Muzeum”, „Ruch Pedagogiczny”, „Drogi”, „Pion”, „Zrąb”, „Rodzina i Dziecko” oraz „Praca Strzelecka"2.

Możemy przypuszczać, że do tak znacznego rozwoju czasopiśmiennictwa pedagogicznego przyczyniły się - licznie powstające - organizacje i stowa-

\footnotetext{
${ }^{1}$ K. Jakubiak, Wychowanie państwowe jako ideologia wychowawcza sanacji. Kształtowanie $i$ upowszechnianie $w$ periodycznych wydawnictwach społeczno-kulturalnych $i$ pedagogicznych, Bydgoszcz 1994, s. 74.

${ }^{2}$ W. Czerniewski, Rozwój dydaktyki polskiej w latach 1918-1954, Wraszawa 1963, s. $439-446$.
} 
rzyszenia nauczycielskie. Nie bez znaczenia było także zapotrzebowanie samych nauczycieli, wychowawców, a nawet rodziców na „nową wiedzę” pedagogiczną i społeczna.

Józef Mirski, ukazujące się wówczas czasopisma pedagogiczne podzielił na trzy grupy:

1) pisma o charakterze informacyjnym, będące najczęściej organami towarzystw i związków nauczycielskich,

2) periodyki fachowe poświęcone metodyce nauczania przedmiotów szkolnych oraz problemom oświaty,

3) czasopisma o charakterze teoretyczno-pedagogicznym ${ }^{3}$.

Do tej ostatniej grupy zaliczył m. in. „Kulturę Pedagogiczną”, „Zrąb” oraz "Oświatę i Wychowanie".

Po „Poradniku w Sprawach Nauczania i Wychowania” oraz „Administracji w Szkołach Średnich Ogólnokształcących i Seminariach Nauczycielskich”, kolejnym organem MWRiOP stało się czasopismo „Oświata i Wychowanie”.

O ile jednak te pierwsze adresowane były głównie do dyrektorów szkół średnich, zakładów kształcenia nauczycieli i do samych nauczycieli, o tyle krąg odbiorców „Oświaty $i$ Wychowania” był znacznie szerszy. Komitet Redakcyjny nadał pismu charakter popularnonaukowy. Dlatego jego struktura obejmowała trzy działy:

I. Z działalności Ministerstwa,

II. Artykuły nadesłane,

III. Kronika ruchu pedagogicznego. Przegląd książek i czasopism pedagogicznych.

Redaktorami czasopisma byli: w latach 1929-1932 Bolesław Kielski, przez dwa następne lata - Hugo Kaufman, a od roku 1935 do 1938 - Eugeniusz Zdrojewski.

Najczęściej publikującymi, stałymi współpracownikami miesięcznika byli przede wszystkim pracownicy MWRiOP: Józef Mirski, Juliusz Balicki, Stanisław Seweryn, Helena Witkowska, Stefan Bakowski, Maria Dzierzbicka, Bogdan Suchodolski. Grono to wspierali częstymi publikacjami Józef Chałasiński, Irena Poseltówna, Jan Dec, Jerzy Ferek-Błeszyński, Władysława Mrozowska, Tadeusz Adamczyk i inni.

Publikacje zamieszczane na łamach miesięcznika miały różny charakter i prezentowały różny poziom (zarówno naukowy, jak i popularny). Redakcji udało się skupić wokół siebie wielu stałych współpracowników, osoby znaczące w środowisku nauczycielskim i najczęściej popierające politykę oświatową sanacyjnych władz.

${ }^{3}$ J. Mirski, O polskim piśmiennictwie i czytelnictwie pedagogicznym, „Przegląd Współczesny" 1931, nr 109, s. 260. 


\section{Założenia edukacji obywatelskiej w wypowiedziach pracowników Ministerstwa}

Problematykę edukacji obywatelskiej odnajdujemy we wszystkich trzech działach czasopisma.

W ideologii wychowawczej Polski międzywojennej wyraźnie rysowały się dwa zasadnicze kierunki:

- narodowo-chrześcijański,

- demokratyczno-obywatelski.

Podstawy narodowo-chrześcijańskiej ideologii wychowawczej wypracowało Stronnictwo Demokratyczno-Narodowe. Pierwsze o nim wzmianki Endecja zawarła w deklaracji programowej z roku 1918, w której podkreślała, iż duch narodowy i religijny stanowić mają podstawę wychowania we wszystkich szkołach. Natomiast zwolennicy opcji demokratyczno-obywatelskiej w naczelne cele wychowania wpisywali powinności obywatelskie (Bolesław Kielski, Lucjan Zarzecki, Władysław M. Borowski, Tadeusz Łopuszański i inni). Miernikiem wartości moralnej narodu miał być według nich tzw. duch publiczny, który należało budować „na tradycji narodowej, powinnościach obywatelskich i realiach aktualnego życia"4.

Dwudziestolecie międzywojenne było okresem panowania ideologii romantycznej, apoteozowania historycznej przeszłości, patriotycznej dumy. Gloria victis - chwała zwyciężonym - to motyw przewodni stosunku do przeszłości $\mathrm{w}$ tym czasie. Historia nie próbowała wówczas odpowiadać na pytania o rację, mądrość, wyniki działania - w samym działaniu, walce, ofiarności dostrzegano wartości najwyższe. W imię tych wartości usiłowano wychować młode pokolenie na kontynuatorów najlepszych tradycji narodowych.

W latach 1923-1925 rozpoczęto na szeroką skalę badania pedagogiczne nad precyzowaniem celów wychowawczych, koncepcji dydaktycznych i ustrojowych. Wysuwano projekty mające dotychczasowy ideał obywatela-bojownika zastąpić ideałem obywatela-pracownika. Uwspółcześniając ideał wychowawczy próbowano czynnik emocjonalny i historyczny zastąpić realizmem.

W miarę rozszerzania się wpływów sanacyjnych wzmacniał się front krytyki dotychczasowej polityki oświatowej. Nie negowano wprawdzie samego wychowania narodowego, ale mocno podkreślano anachroniczność ideologii wyrosłej w czasach zaborów, brak czynnika państwowości, lojalności wobec państwa, a także nieumiejętność współżycia obywatelskiego w ramach suwerennego państwa.

Na łamach „Oświaty i Wychowania” już we wrześniu roku 1929 pojawiły się założenia, a nawet zalecenia MWRiOP dotyczące kreowania nowego ideału

\footnotetext{
${ }^{4}$ W. M. Borowski, Ogólne zarysy wychowania narodowego, Warszawa 1918, s. 58.
} 
wychowawczego. Opublikowano referat ministra Sławomira Czerwińskiego, w którym znajdujemy krytykę rządów przedmajowych za to, że nie potrafiły wypracować potrzebnego Polsce ideału wychowawczego. Poza miłością i ofiarnością dla narodu i ojczyzny należało, jego zdaniem, wykształcić poczucie obowiązków wobec państwa, społeczeństwa i narodu. Dlatego w celach nauczania, obok tez podkreślających konieczność wdrażania uczniów do życia obywatelskiego i budowania wśród nich odpowiedzialności za bezpieczeństwo państwa i społeczeństwa polskiego, wprowadzał element ,przywiązania do państwa polskiego".

Pożądanym ideałem wychowawczym według Czerwińskiego mógł być jedynie typ obywatela-pracownika i bojownika w jednej osobie. Taki typ, który na co dzień będzie rzetelnie pracował, „a w razie potrzeby i świętym zapałem walki potwierdzi swój czynny, szczery patriotyzm"s.

Referat Czerwińskiego to w zasadzie koncepcja wychowania państwowego, przyjęta jako sanacyjna wersja edukacji obywatelskiej. Bazowała ona na założeniu, że w pracy wychowawczej należy łączyć elementy romantycznego entuzjazmu i pozytywistycznych umiejętności pracy.

Jak stwierdziła Kalina Bartnicka, problem ideału wychowawczego „chwycił". Społeczeństwo nie dojrzało jeszcze do zrozumienia społecznej istoty zagadnień oświatowych, wierzyło w magiczną moc wychowania ${ }^{6}$.

Głosząc postulat wychowania człowieka woli i czynu, pracy i myśli społecznej, sanacja dążyła zarazem do zachowania i utrwalenia ustroju Polski. Zatem adaptacja młodego pokolenia do życia w warunkach klasowego ustroju kraju była wspólna ideologii endeckiej i sanackiej. Tak pojmowane wychowanie nie wymagało radykalnej przebudowy ówczesnych programów nauczania. W praktyce sprowadzono tę przebudowę do:

1) uzupełnienia programów treściami bardziej współczesnymi, związanymi z czynem orężnym obozu peowiacko-legionowego i dążeniami obozu sanacyjnego,

2) wprowadzenia do procesu wychowania kultu osoby Józefa Piłsudskiego,

3) zastapienia indywidualizmu pedagogicznego, państwowotwórczą pedagogiką społeczną,

4) wyrobienia w młodzieży poczucia odpowiedzialności, karności i lojalności wobec sanacyjnego obozu rządzącego ${ }^{7}$.

Na łamach „Oświaty i Wychowania” czytamy słowa ministra Władysława Jędrzejewicza adresowane do młodzieży - „I uwierzył Wam Ten, który z kajdan wyzwolił nasz kraj i nowe państwo zbudował, że Wy, młodzież, kiedy

5 St. Czerwiński, O ideat wychowawczy szkoty polskiej, „Oświata i Wychowanie” [dalej OiW] 1929, s. 357.

${ }^{6}$ K. Bartnicka, Wychowanie państwowe, „Rozprawy z Dziejów Oświaty” 1972, t. XV, s. 83.

${ }^{7}$ F. W. Araszkiewicz, Szkoła średnia ogólnoksztatcaca w Polsce w l. 1918-1932, Wrocław 1972, s. 185-186. 
dorośniecie, to miłować będziecie ojczyznę - jak On"»8. W przemówieniu minister podkreślał zasługi Marszałka w tworzeniu odrodzonego państwa polskiego i jego wielką miłość do ojczyzny. Wskazywał tym samym najlepszy wzór do naśladowania:

Cokolwiek czynić będziesz w życiu, a nawet co dzisiaj czynicie - to z myślą o Polsce, jak to czynił On. Ucząc się, kształcąc, rozwijając, starać się będziecie o to, by państwo polskie dobrych miało obywateli, godnych imienia Polaka?

Problematykę edukacji obywatelskiej na łamach czasopisma wielokrotnie podejmowała, związana $\mathrm{z}$ obozem rządowym, Irena Posseltówna. W swoich artykułach najczęściej zajmowała się problemami edukacji obywatelskiej na terenie szkoły oraz w programach organizacji młodzieżowych ${ }^{10}$.

$\mathrm{Z}$ istoty szkoły wynika, że jest ona niepełnym środowiskiem działania. Niemniej musi odtwarzać warunki życia społecznego w jego realnych problemach i trudnościach. A zatem szkoła jako instytucja wychowawcza powinna być przede wszystkim miejscem solidnej i twórczej pracy. Nauczyciel prowadząc młodzież ku solidnej pracy własnej, winien jednocześnie urabiać w niej poszanowanie dla wszelkiej pracy zarówno fizycznej, jak i umysłowej, zbiorczej czy jednostkowej.

Istotną rolę do odegrania miała, według Posseltówny, klasa szkolna, jako pierwsza grupa społeczna, z którą spotykało się dziecko po wyjściu z kręgu rodziny:

Klasa musi stać się pierwszym filtrem uczuć i instynktów społecznych, stąd atmosfera klasy, stopień zżycia się uczniów na jej terenie, owa „etyka” stosunków koleżeńskich jest niezmiernie ważna z punktu widzenia wychowania obywatelskiego młodzieży ${ }^{11}$.

Każda godzina spędzona przez ucznia w szkole to godzina wychowawcza. Jednakże realizacja wychowania obywatelskiego to całokształt wysiłków szkoły, rodziców i samych uczniów.

Przywódca i ideolog grupy zrębowców Janusz Jędrzejewicz za podstawowe zagadnienie wychowawcze epoki uznał ukształtowanie człowieka, który będzie zdolny i chętny brać świadomy udział w społecznym życiu zbiorowości.

Takie samo zadanie stawiał przed wychowaniem przywódca BBWR, płk Walery Sławek, który w swoich wystapieniach nawoływał do wspólnej pracy na

\footnotetext{
${ }^{8}$ W. Jędrzejewicz, Przemówienie Pana Ministra W. Jędrzejewicza do młodzieży, OiW, 1935, nr 5, s. 322.

${ }^{9}$ Tamże, s. 322.

${ }^{10}$ I. Posseltówna, Organizacja życia szkolnego a wychowanie obywatelskie młodzieży, OiW, 1934, nr 3-5.

${ }^{11}$ Tamże, s. 133.
} 
rzecz silnego państwa. Wychowanie państwowe stało się nakazem chwili. Nie było ono jednak postrzegane jako doktryna społeczna ani doktryna wychowawcza.

Na podłożu socjologii i filozofii, w czasopismach rozwinęła się dyskusja na temat ustalenia relacji miedzy pojęciami „państwo”, „wychowanie państwowe”, „ideał wychowawczy” oraz najogólniejszych wypływających stąd wskazówek dla praktyki wychowawczej. Z prowadzonych dyskusji wyłaniały się podstawowe zadania wychowania państwowego - wszechstronny rozwój osobowości i indywidualności jednostki, ale ograniczonej interesem dobra publicznego i państwa, jednostki, silnej, odpowiedzialnej i twórczej, związanej z życiem i potrzebami rzeczywistości polskiej.

Po roku 1935, w związku z zaostrzeniem kursu politycznego sanacji po uchwaleniu nowej konstytucji i po śmierci J. Piłsudskiego, daje się zauważyć wyraźny kryzys wychowania państwowego. Nowa konstytucja, którą traktowano jako testament marszałka, wyznaczyła nowe cele wychowawcze. Określił je J. Jędrzejewicz w Nowej deklaracji ideowej grupy Zrąb. Te nowe cele to: poczucie odpowiedzialności w sprawach państwowych, zdecydowana postawa obronna wobec obcej przemocy, ugruntowanie świadomości narodowej.

W myśl wskazań naczelnego wodza marszałka Śmigłego Rydza przygotowanie całego naszego społeczeństwa do obrony kraju staje się naczelnym zadaniem wszystkich dziedzin pracy państwowej i społecznej.

Tymi słowy rozpoczął swój odczyt, opublikowany na łamach „Oświaty i Wychowania”, Stanisław Seweryn ${ }^{12}$. Zwracając uwage na trudną sytuacje międzynarodową Polski nawoływał, aby każdy obywatel, bez względu na wiek i płeć, był przygotowany nie tylko do obrony państwa, ale także do współdziałania w pracy nad wzmocnieniem jego sił i zasobów.

Powrócił obywatel-żołnierz. Silny psychicznie i fizycznie młody człowiek, zdyscyplinowany i karny, aby mógł sprostać wymaganiom nowoczesnej walki na froncie i ewentualnego przetrwania jej na tyłach ${ }^{13}$.

Przysposobienie młodzieży do obrony kraju podzielono na ogólne, które miało być realizowane przez całe szkolnictwo, oraz wojskowe, które weszło jako przedmiot obowiązkowy do programu nauczania. Formą nauczania tego przedmiotu był hufiec szkolny, gdzie zajęcia prowadzili także zawodowi oficerowie różnych specjalności ${ }^{14}$.

Celem przysposobienia wojskowego dla chłopców było opanowanie podstawowych technicznych wiadomości i sprawności wojskowych, dla

\footnotetext{
${ }^{12}$ St. Seweryn, Przygotowanie młodzieży do obrony państwa, OiW, 1937, nr 6, s. 547.

${ }^{13}$ Tamże, s. 548.

${ }^{14}$ Tamże; DzUrz MWRiOP, 1937, nr 12, poz. 369.
} 
dziewcząt natomiast przewidziano naukę ratownictwa i obrony przeciwpożarowej ${ }^{15}$.

Przysposobienie wojskowe wysuwano na czoło realizowania idei wychowania państwowego, obok czynnika emocjonalnego, wprowadzało bowiem młodzież w sferę czynu i oddziaływało bezpośrednio na wolę wychowanków. Miało być podstawową formą czynu i mocnego przeżycia wdziedzinie obywatelsko-państwowej, jedyną, która naprawdę młodzież zadowalała, gdyż łączyła się bezpośrednio z zagadnieniami państwa i z czynami społeczeństwa dorosłych. Tym samym dawała młodzieży prawdziwą satysfakcję, kojarzyła się $\mathrm{z}$ bronią, żołnierzem i mundurem. Dzięki temu P-W urabiało wolę, charakter, ćwiczyło w karności, sprzyjało koleżeńskim relacjom, wytwarzało więzi społeczne.

Zmilitaryzowanie programów nauczania - zwłaszcza szkoły średniej sprawiło, że wychowanie państwowe przestało w praktyce być zgodne z pierwotnymi założeniami jego twórców.

\section{Edukacja obywatelska w koncepcjach pedagogów}

Jednym z najważniejszych zadań czasopisma „Oświata i Wychowanie” było wypracowanie i rozpropagowanie nowego ideału wychowawczego oraz programu wychowawczego. Ogromny udział w tym przedsięwzięciu miał Józef Chałasiński, dla którego edukacja obywatelska była „edukacją do demokracji”. W artykule Nauka obywatelstwa na poziomie szkoły powszechnej i niższego gimnazjum $^{16}$ do najważniejszych zadań wychowania obywatelskiego zaliczył

przygotowanie młodzieży do przejścia z jej pierwotnych form współżycia do życia społecznego w wielkim, nowoczesnym społeczeństwie demokratycznym, przystosowanie jej psychiki do psychologicznie i socjologicznie odmiennej struktury wielkiego społeczeństwa ${ }^{17}$.

Do najważniejszych czynników wychowania obywatelskiego zaliczał naukę szkolną, organizację szkoły oraz życie szkolne młodzieży. Nauka szkolna to najlepsze narzędzie rozwoju umysłowego. Dzięki niej młodzież przyswaja sobie wiedzę o polityce, ekonomii czy strukturze społeczeństwa. Uczy się myślenia pojęciowego, nabywając umiejętności abstrahowania i uogólniania. Przezwyciężając zaś trudności w nauce, kształtuje charakter.

\footnotetext{
${ }^{15}$ T. Adamczyk, Nowe zarzadzenie $w$ sprawie organizacji przysposobienia młodzieży szkolnej do obrony kraju, OiW, 1937, nr 9-10, s. 796-799.

${ }^{16} \mathrm{~J}$. Chałasiński, Nauka obywatelstwa na poziomie szkoły powszechnej i niższego gimnazjum, OiW, 1929, nr 1, s. 49.

${ }^{17}$ Tamże.
} 
Przy tradycyjnych sposobach nauczania nie można jej [nauce szkolnej - W. L.] jednak przypisywać pozytywnego znaczenia dla kształtowania postaw, uczuć i skłonności obywatelskich. Jako środek wychowania obywatelskiego zyskuje ona bardzo na znaczeniu dopiero wtedy, gdy zostaje uspołeczniona, związana z realnym życiem społeczeństwa, gdy dołącza się do niej współzawodnictwo i współdziałanie, gdy staje się treścią grupowego życia ${ }^{18}$.

Organizacja szkoły tylko wtedy może mieć znaczenie dla edukacji obywatelskiej, kiedy zerwie z przestarzałymi kanonami nauczyciel - zwierzchnik, uczeń - podwładny, a także wtedy, gdy nauczyciel będzie umiał zjednać sobie sympatię uczniów.

Jednakże najważniejsze dla edukacji obywatelskiej jest „nieoficjalne życie szkolne uczniów", czyli ten czas, który uczniowie spędzali po lekcjach i innych zajęciach obowiązkowych.

W tych właśnie środowiskach, w których młodociana jednostka występuje związana licznymi węzłami z gromadą, w których pracuje i bawi się, kształtują się uczucia, skłonności i pojęcia obywatelskie $^{19}$.

A zatem, aby kształcić przyszłych obywateli, szkoła musiała dać uczniom możliwość korzystania zarówno z praw obywatelskich, jak i pozwolić im wypełniać obowiązki obywatelskie. Temu celowi miały służyć organizacje społeczne, przede wszystkim samorząd szkolny, ale także wszystkie te, które pozostawały w kręgu zainteresowań młodzieży, a które potrafiły ukształtować wiele postaw obywatelskich, poczucie własnej godności, współzawodnictwo czy odpowiedzialność. Wśród takich organizacji autor wymieniał: drużyny harcerskie, drużyny sportowe, obozy przysposobienia wojskowego, kluby dobrych obywateli, kluby oszczędzania itp.

Doświadczenia społeczne uczniów Chałasiński cenił znacznie wyżej niż programy wszelkich przedmiotów nauki obywatelskiej. Niemniej dostrzegał też potrzebę właściwego przygotowania nauczycieli do edukowania obywatelskiego. Najlepszym sposobem była tu szeroka wiedza socjologiczna:

Socjologia zajmuje się właśnie badaniem społecznych dążności i uczuć, znaczeniem współżycia społecznego dla umysłowego, uczuciowego i moralnego rozwoju człowieka, zjawiskami wzajemnego oddziaływania, analizą konfliktów społecznych, solidarności i współdziałania ${ }^{20}$.

Rok później, w artykule Dwie koncepcje nauki obywatelstwa $i$ dwa typy podręczników $^{21}$ Chałasiński precyzował, że celem nauki obywatelstwa jest

${ }^{18}$ Tamże, s. 50-51

${ }^{19}$ Tamże, s. 53.

${ }^{20}$ Tamże, nr 2, s.165.

${ }^{21}$ J. Chałasiński, Dwie koncepcje nauki obywatelstwa i dwa typy podręczników, OiW, 1930, nr 9, s. 844. 
przygotowanie do życia społecznego, a główne jej zadania to nie podawanie wiadomości o państwie czy życiu gospodarczym, ale zainteresowanie młodzieży problemami życia zbiorowego i pobudzenia jej do myślenia kategoriami społecznymi. Stosowane zatem w nauce obywatelskiej podręczniki muszą zawierać wiedzę jednolita, skłaniającą ucznia do samodzielnych refleksji. Wprowadzanie odrębnych działów poświęconych ekonomii, prawu, społeczeństwu itp. jest pozbawione sensu.

W roku 1930 na łamach czasopisma pojawił się artykuł Józefa Mirskiego Polska myśl wychowawcza, który był próbą określenia głównych tendencji w pedagogice polskiej. Autor dostrzegał tendencję narodową, demokratyczną i rozwijającą się równolegle $\mathrm{z}$ nimi myśl naukowo-pedagogiczną. Dwie pierwsze tworzyły tzw. naczelne wartości wychowawcze, trzecia zaś wyjaśniała je i racjonalizowała oraz poszukiwała ,środków realizacyjnych"22.

Mirski wskazywał na poglądy i zasady, które składały się na polską pedagogikę narodową, odwołując się do Bronisława Trentowskiego i Ewarysta Estkowskiego. W Polsce niepodległej, odwołując się do sprawiedliwości społecznej w wychowaniu, podkreślił demokratyczną ideę szkoły jednolitej, czyli szkoły równych szans. W tym zakresie upatrywał zrównania pedagogiki polskiej z pedagogiką Zachodu:

I w tej dziedzinie Polska czuje się członkiem wielkiej rodziny narodów kulturalnych i wraz z nimi dąży do wspólnego celu, mianowicie do wychowania jednostek dzielnych i pełnych charakteru, umiejących w sercu i w czynie łączyć gorącą miłość własnego narodu, ojczyzny i państwa z prawdziwym, szlachetnym poczuciem obywatelstwa ogólnoludzkiego ${ }^{23}$.

Do dyskusji nad istotą wychowania państwowego włączył się także Włodzimierz Gałecki, żarliwy propagator tych idei na kursach nauczycielskich niemal we wszystkich większych miastach Polski.

Dla Gałeckiego wychowanie państwowe było równoznaczne z wychowaniem obywatelskim. Uzasadniał także, że wychowanie państwowe musi opierać się na narodowym, tzn. na własnej kulturze i tradycji, gdyż to jest najważniejsza i najmocniejsza podstawa wychowania w państwie demokratycznym:

Nam będzie chodzić o polskie wychowanie państwowe, a więc oparte o polski, odwieczny, silnie demokratyczny ustrój państwowy, przy którym każdy obywatel staje się współtwórcą potęgi państwowej i czynnikiem współodpowiedzialnym za losy państwa ${ }^{24}$.

\footnotetext{
${ }^{22}$ J. Mirski, Polska myśl wychowawcza, OiW, 1930, nr 10, s. 929.

${ }^{23}$ Tamże, s. 932.

${ }^{24}$ W. Gałecki, Wychowanie państwowe, OiW, 1931, nr 7, s. 612.
} 
Stawiając znak równości między wychowaniem państwowym i wychowaniem obywatelskim Gałecki wskazywał na ich wspólne cele -

urobienie czynnych i twórczych obywateli [...], którzy potrafiliby możliwie szeroki rozwój własnej indywidualności obracać przede wszystkim na korzyść rozwoju dobra i potęgi Najjaśniejszej Rzeczypospolitej ${ }^{25}$.

Wychowanie państwowe miało się opierać w znacznej mierze na odpowiednio prowadzonym nauczaniu. Dlatego też autor przywiązywał dużą wagę do nauki o Polsce, nauki obywatelstwa, która dawała całokształt wiedzy o Ojczyźnie, zaznajamiając jednocześnie z pracami i obowiązkami obywateli.

W kolejnych latach pojawiały się artykuły dydaktyczne, mówiące o tym, w jaki sposób treści obywatelskie można realizować w konkretnych przedmiotach czy działaniach popularyzatorskich (a może nawet propagandowych). Były to $\mathrm{m}$. in.: Stanisława Pawłowskiego, Wychowanie państwowe w nauczaniu geografii; Jana Deca, Oświata pozaszkolna jako dziat pracy państwowej oraz referaty wygłoszone na Kongresie Pedagogicznym w roku 1931 w Wilnie: Karola Makucha, Cele i zadania szkoły polskiej; Stanisława Somorowskiego, Rola poszczególnych przedmiotów nauczania, jako środków do osiagnięcia celów wychowawczych oraz Hanny Pohoskiej, Społeczno-państwowe zadanie wychowawczej nauki o Polsce wspótczesnej.

W podsumowaniu wystąień kongresowych K. Makuch sformułował dwie tezy;

1. Szkoła jest organem wychowania społeczno-państwowego. Państwo rozumiane [...] jako grupa społeczna, kulturalno-terytorialna.

2. Cele i zadania szkoły wszelkiego typu wyznaczać i określać należy u nas w Polsce jedynie na tle grupy społeczno-państwowej, jej potrzeb i konieczności, w kierunku utrwalenia odzyskanego bytu niepodległości państwowej, rozwoju kultury, mocy i potęgi Państwa w ustroju republikańsko-demokratycznym ${ }^{26}$.

\section{Edukacja obywatelska w organizacjach młodzieżowych}

Szkoła, szukając sposobów realizacji postulatu wychowania obywatelskiego i samowychowania, dążyła do stworzenia jak największej liczby organizacji i z tego tytułu domagała się uznania.

Z punktu widzenia ucznia organizacje uczniowskie dawały różnorakie korzyści - zależne od ich charakteru. W jednej bowiem mógł on rozszerzyć wiadomości, których nauczyciel nie podał na lekcjach (kółka naukowe), w in-

\footnotetext{
${ }^{25}$ Tamże, s. 616.

${ }^{26}$ Kongres Pedagogiczny w Wilnie, OiW, 1931, nr 7, s. 686.
} 
nych (samorząd, SKO) przyzwyczajał się do życia organizacyjno-społecznego. Harcerstwo zaś łączyło w sobie głębokie zasady etyczne z osobistą sprawnością i zaradnością.

Na łamach czasopisma „Oświata i Wychowanie” ograniczono się głównie do spraw samorządu szkolnego i jego różnych form oraz działalności harcerstwa.

Na gruncie szkoły samorząd stał się podstawą życia zespołowego. Rudolf Taubenszlag wyróżnił dwa cele samorządu uczniowskiego - socjalny, którego zadaniem było uspołecznienie wychowanka, oraz indywidualny, prowadzący do usamodzielnienia ucznia ${ }^{27}$.

Ucząca w gimnazjum Anzelma Żebrowska istniejące samorządy szkolne podzieliła na trzy grupy:

- Pełne, rozbudowane, działające na terenie całej szkoły,

- Częściowe, istniejące tylko w niektórych klasach,

- Rozbudowane wyłącznie na podstawie samopomocy koleżeńskiej ${ }^{28}$.

Podstawową komórką pracy samorządowej była klasa, stanowiąca zawsze zespół zwarty w sobie, zazwyczaj obdarzony dużą swobodą działania, mająca swój zarząd, a niekiedy również regulamin.

Naczelne cele, jakie stawiały sobie owe samorządy szkolne, to:

1) urabianie charakterów, uczuć etycznych, rozwój postaw społecznych, odpowiedzialności za swe czyny, karności;

2) rozwój życia koleżeńskiego, samopomoc, popieranie kółek naukowych i sportowych, utrzymywanie ładu i porządku w szkole;

3) rozwijanie inicjatywy, umiejętności obradowania, dyskutowania i współdziałania.

Obok R. Taubenszlaga, badania dotyczące funkcjonowania samorządów szkolnych w Polsce przeprowadził Adam Zieleńczyk. Relacje z badań w „Oświacie i Wychowaniu” publikowano w roku 1932, w numerach 4, 5 i 6.

Za typowy samorząd tego okresu Zieleńczyk uznał Naczelną Organizację Młodzieży, działającą w Gimnazjum Męskim im. J. I. Kraszewskiego w Białej Podlaskiej ${ }^{29}$.

Statut tej organizacji zakładał następujące cele i zadania:

- wykształcenie społeczne przyszłego obywatela Polski,

- podniesienie poziomu ideowego młodzieży,

- kształcenie moralne i umysłowe, wyrobienie towarzyskie ${ }^{30}$.

${ }^{27}$ R. Taubenszlag, Samorzqd uczniowski jako czynnik wychowania spotecznego. Teoria praktyka, zalety - wady, wskazania, Warszawa 1932, s. 9-16.

${ }^{28}$ A. Żebrowska, Samorzą szkolny na terenie warszawskich państwowych szkół ogólnoksztatcacych, OiW, 1933, nr 3, s. 165.

${ }^{29}$ A. Zieleńczyk, Samorzą uczniowski w Polsce, OiW, 1932, nr 4, s. 529.

${ }^{30}$ Tamże. 
Do osiagnięcia celów samorządowych służyć miały wspólnie wypracowane formy działań - praca ideowa, samopomoc koleżeńska, systematyczne zebrania wszystkich członków, referaty na tematy obywatelskie i dyskusje nad problemami nurtującymi młodzież, praca w kołach naukowych, wspólne zabawy.

Skauting polski, noszący nazwę ,harcerstwa” wywodzącą się od staropolskiego słowa „harcerz” oznaczającego rycerza wyróżniającego się dzielnością i inicjatywą oraz wiernością był prowadzony ściśle według metody Baden-Powella. Pierwsze zastępy i drużyny skautów powstały w Polsce w roku 1910, w Warszawie i Lwowie. W roku 1929 miano „harcerz” nosiło już w Polsce 57 tysięcy dziewcząt i chłopców ${ }^{31}$.

W latach trzydziestych wyraźnie zaznaczył się samowychowawczy charakter harcerstwa. Traktowane jako „Służba Bogu, Polsce i ludziom” spontanicznie określało swoje ideały. A ideałami tymi były: „Polska dobrze zorganizowana, kulturalna i sprawiedliwa. Polska przyszłości, to Polska ludzi pracy"32.

Prawo harcerskie ustalało cechy potrzebne obywatelowi: miał to być człowiek prawdy, odznaczający się pozytywnym stosunkiem do niej jako do czegoś niezmiennego. Harcerz to człowiek życzliwy, miłujący przyrodę, karny i odpowiedzialny.

Harcerstwo łączyło w sobie głębokie zasady etyczne z osobistą sprawnością i zaradnością, propagowało szlachetne hasła altruistyczne. Traktując harcerstwo jako dopełnienie pracy wychowawczej szkoły uważano, że musi ono utrzymywać bliski z nią kontakt i podlegać kontroli czynników szkolnych ${ }^{33}$.

Włodzimierz Gałecki, tak jak większość ówczesnych pracowników MWRiOP, uważał, że harcerstwo powinno działać raczej wśród młodzieży młodszej, traktując je raczej jako doskonałą formę pracy wychowawczej i fazę początkowac której finalnym uzupełnieniem miało być przysposobienie wojskowe ${ }^{34}$.

Wielość wrażeń i przeżyć szkolnych, praca w licznych kierunkach, stałe obcowanie z grupami społecznymi, brak możliwości skupiania się i pogłębiania wiadomości, przyzwyczajenie do powierzchownego ich chwytania prowadziły do urabiania

półinteligentów, ludzi unikających trudu dorabiania się wyższej struktury duchowej, zadowalających się pozorami kultury, jej zewnętrznymi przejawami, a nie wgłębiających się w jej istotną treść ${ }^{35}$.

\footnotetext{
${ }^{31}$ S. Sedlaczek, Harcerstwo męskie i żeńskie w Polsce, OiW, 1930, nr 9, s. 841-844.

${ }^{32}$ Tamże, s. 841.

${ }^{33}$ S. Sedlaczek, Harcerstwo w szkole, OiW, 1930, nr 2, s.144.

${ }^{34}$ W. Gałecki, Wychowanie państwowe, OiW, 1931, nr 7, s. 631.

${ }^{35}$ L. Sablewicz, Hodowla pótinteligencji, „Gimnazjum” 1936, nr 7, s. 241.
} 
W czasopiśmie „Oświata i Wychowanie”, a także w innych czasopismach pedagogicznych, popularyzowano koncepcję wychowawczą sanacji poprzez przełożenie głównych przesłanek teoretycznych na język praktyki pedagogicznej. Na ich łamach przedstawiano metody, środki i formy oddziaływań wychowawczych. Prezentowano doświadczenia wychowawcze nauczycieli i szkół w zakresie wychowania państwowego. Publikacje te przyczyniły się więc znacznie do wypracowania i upowszechnienia sanacyjnej polityki oświatowej i ideologii wychowawczej. Oczywiście, jako że było to czasopismo rządowe, nie publikowano $\mathrm{w}$ nim wypowiedzi krytycznych pod adresem wychowania państwowego i jego realizatorów. Tymczasem wprowadzenie sanacyjnego ideału wychowawczego nie oznaczało jego całkowitego zwycięstwa. Nadal istniał wyraźny opór endecji i lewicy przeciwko wychowaniu państwowemu. Lewicowa krytyka kierowała się przeciw uproszczeniom, które ustępowały ideologii wychowania państwowego, a zwłaszcza przeciwko utożsamianiu tegoż z wychowaniem obywatelskim, co prowadziło do przesadnej karności, zdyscyplinowania i posłuchu dla władzy. 